\title{
Utilization of Corn Husk for Tissue Papermaking
}

\author{
Natalia Suseno ${ }^{1, \text { a) }}$, Marisca E Gondokesumo ${ }^{2}$ and Puspita R Permatasari ${ }^{1, \text { b) }}$ \\ ${ }^{I}$ Department of Chemical Engineering, Faculty of Engineering, University of Surabaya \\ Jl. Raya Kalirungkut, 60293, Surabaya Indonesia \\ ${ }^{2}$ Faculty of Pharmacy, University of Surabaya, Jl. Raya Kalirungkut, 60293, Surabaya Indonesia \\ a) Corresponding author: suseno.natalia@yahoo.com \\ b) puspitarahayup@gmail.com
}

\begin{abstract}
The demand of tissue papers is increasing with the population increase. This will definitely increase the need of wood fibers as the main raw material. However, due to the wood shortages, there have been many attempts to use nonwood fibers as substitutes for papermaking. In Indonesia, corn production has gradually increased for the last 5 years, hence it also has an impact on the raising in the amount of corn husk waste. Corn husk has a high cellulose content which suitable to be used as a raw material for tissue papermaking. In this experiment, soda pulping process was conducted to remove out lignin. The resulting tissue paper will be added with additives that have antimicrobial properties of chitosan and mangosteen peel for the purpose of increasing the tensile strength or absorption of water. The aim of this research is to study the effect of depending variables (temperature and $\mathrm{NaOH}$ concentration) on chemical composition (cellulose and lignin content), and physical properties including water absorption and tensile strength. The research was started with the initial process of removing the lignin content in the pulp by pretreating delignification using the sodium hydroxide $(\mathrm{NaOH})$ process with several variations in concentration $(4-10 \%)$, and temperature $\left(60-90^{\circ} \mathrm{C}\right)$ for 1.5 hours. To obtain tissue with a good physical condition, it has been influenced by the optimum chemical composition containing high cellulose and low lignin content, high tensile strength and water absorption. The optimum conditions for tissue paper in this study were at $90^{\circ} \mathrm{C}$ and $4 \%$ of $\mathrm{NaOH}$ concentration. The next step will be to vary the composition of the additive in order to obtain the effect of physical properties (tensile strength and water absorption).
\end{abstract}

\section{INTRODUCTION}

Indonesia is the one of the biggest agrarian countries with plenty products of agriculture, crops, and fishery. Agricultural sector would relate with industrial's material supply such as corn (Zea mays L.). According to BPS data, corn production has been increasing gradually during five years, accordingly Indonesia's corn production rose $30,055,623$ tons [1]. The higher corn production, the more waste of corn husk gaining. Local people usually process the corn husk for paper crepes, artworks, farming feeds, or else biomass in renewable energy [2]. However, corn husk has slowly degraded for it would ruin the environment.

On the other hand, the main material of tissue papermaking has been using wood substance. The non-wood material alternative should be found in tissue papermaking, then it has invented at several options, such as corn husks, rice straw, wheat stalks, bagasses, bamboos, etc. [3]. Based on those alternatives, the corn husk is the potential material for tissue papermaking which has high cellulose content. The chemical components of corn husk are protein 3,7\%, fat $1 \%$, crude fiber $86,7 \%$, ash $0,8 \%$, starch $7,3 \%$ and sugar $0,34 \%$, while the crude fiber content includes: $63 \%$ hemicellulose, $23 \%$ cellulose, $18 \%$ lignin, the remaining $9.9 \%$ extractive substances [3].

Tissue that comes from non-wood materials has a shorter fiber length than wood fibers, therefore tensile strength of non-wood tissue is lower than wood tissue. To overcome this problem thus the additives are needed. The additives compound such as chitosan that the most using is sizing agent for improving tissue structures by fulfilling each component of tissue paper. Moreover, chitosan and mangosteen peel would also include in tissue papermaking as additives [4-6]. Those components have antibacterial activities likewise people with highly sensitive skin may use appropriately. The addition of chitosan to paper making as a surface coating forms a strong thin layer and it can 
improve the material's performance against mechanical, gas-retaining and antimicrobial properties [6]. For example, the combination of chitosan with cellulose increases the mechanical strength and coloring ability of paperboard, and it can have an anti-electrostatic effect on fabric fibers. The addition of chitosan to the batch system in the laboratory is done by immersing or coating on the surface. The purpose of the coating is to provide better paper properties especially in terms of tensile strength, folding resistance and tear resistance.

This research relates to the urgency of continual non wood utilization. It would eradicate wood stock and trees while following on replanting involve a long time period. Consequently, the solution of tissue papermaking material should be invented to overcome wood highly using in huge tissue demand. The main purpose of this research is to transform waste utilization toward more valuable stuff. The result would support waste production from organic material within highly cellulose components as nature as biopolymer compounds.

Several researchers have conducted research on making paper from corn waste, but few have discussed the effect of delignification process conditions on the physical properties of tissue paper. In this research, in order to study the effect of delignification process conditions (temperature and $\mathrm{NaOH}$ concentration) on chemical composition (cellulose and lignin content), and physical properties including water absorption and tensile strength. Several experimental stages were carried out which involved making tissue paper without adding additives and adding chitosan and mangosteen peel as additives.

\section{MATERIAL AND METHODS}

\section{Materials}

The corn husk was used as raw material of biomass, sodium hydroxide (PT Tjiwi Kimia, 95\%). The materials used for additives were mangosteen peels (Garciniamangostana) and chitosan (DD: 75\%). The materials used for analysis were ethanol (Sigma Aldrich, 96\%), benzena (Sigma Aldrich, 99,5\%), acetic acid (Sigma Aldrich, 100\%), and sulfuric acid (Sigma Aldrich, 98\%).

\section{Methods}

\section{Papermaking Process}

The Corn Husk was cut, milled, and screened prior to pulping. In the soda pulping process of corn husk, various $\mathrm{NaOH}$ concentration $(4,6,8,10) \% \mathrm{w} / \mathrm{v}$, delignification temperature $(60,70,80,90){ }^{\circ} \mathrm{C}$ were varied. Corn husk was delignified with $\mathrm{NaOH}$ solution with a ratio $1: 30(\mathrm{w} / \mathrm{v})$ in a laboratory flask for 1.5 hour. The delignified corn husk was filtrated to separate pulp and filtrate. Wet pulp should be neutralized through water washing and drying in the oven. The dried pulp was characterized by its chemical composition (cellulose and lignin contents). The dried pulp was weighted to get certain gramature values of tissue papers. The pulp was added with water and blended with motor stirrer in $300 \mathrm{rpm}$. The mixtures were poured into a filter and pressed by water aided by a gravity force to remove out water and drying. The tissue produced is in the form of a square sheet with dimensions of length and width of $30 \times 30 \mathrm{~cm}$, according to the dimensions of the filter used in the network formation process. The tissue paper sheet was dried and characterized by its chemical composition (cellulose and lignin contents). The next step was the resulting tissue paper sheet soaked with additives: mangosteen peel and chitosan. There were various concentration on additivies ratio, such as mangosteen peel were $5,10,15,20$, and $25(\% \mathrm{w} / \mathrm{v})$ and chitosan were $2,4,6$, 8 , and 10 (\%dried pulp). The tissue paper sheets coating with the mangosteen peel by which was dissolved in water (ex: 5 grams mangosteen peel in $100 \mathrm{ml}$ ) and the chitosan was dissolved in $0.3 \%$ acetic acid in $100 \mathrm{ml}$. The tissue paper sheet coated with the additive was dried and characterized by physical properties (tensile strength and water absorption). The experimental flow chart is shown in Figure 1 below. 
The Corn Husk was cut, milled, and screened

Delignified the corn husk (soda pulping process), $\mathrm{C}_{\mathrm{NaOH}}=4-10 \% \mathrm{w} / \mathrm{v}, \mathrm{T}=60-$

$90^{\circ} \mathrm{C}, \mathrm{R}=1: 30(\mathrm{w} / \mathrm{v}), \mathrm{t}=1.5 \mathrm{~h}$

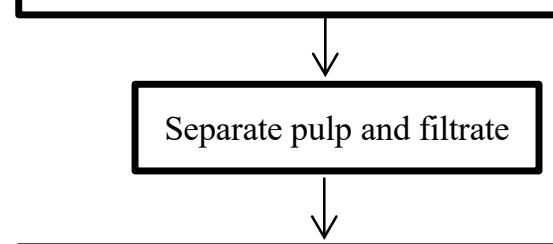

Wet pulp was neutralized, washed, and dried

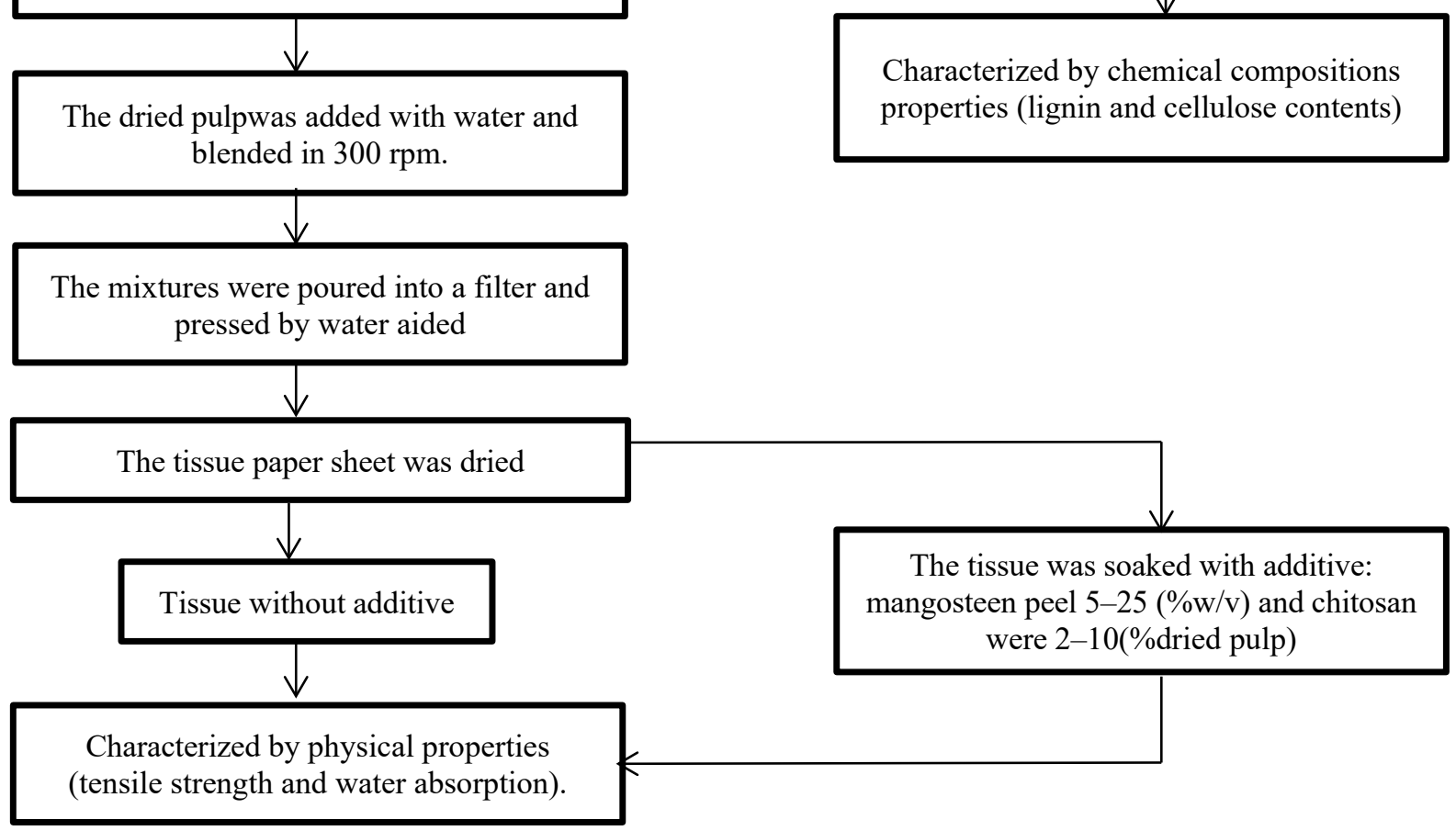

FIGURE 1. Experiment Flow Chart

\section{Paper Characterizations}

The characteristics of the tissue paper produced were observed for its constituent chemical components including cellulose and lignin, and their physical properties (tensile strength and water absorption). The analysis of the chemical components of tissue sheets using the test method for pulp and paper was characterized chemically according to the Indonesian National Standard (SNI), namely: cellulose (SNI 0444-2009) and lignin (SNI 0492-2008). Furthermore, the characterization of physical properties includes the measurement of tensile strength (SNI ISO 1924-2: 2010 and water absorption using the Cobb method (SNI 0499: 2008). 


\section{Experimental Design}

The optimum condition in the delignification process of the tissue paper produced can be determined by statistical methods. The statistical method used is the multiple regression method (if there are no interaction between predictor variables) or the stepwise regression method (if there are interaction between predictor variables). The software of Minitab was performed to analyze the results. Determining the significance of the experiments that have been carried out, it can be seen whether the method has met the requirements of the existing significance $(\mathrm{p}<0.05)$.

\section{RESULTS AND DISCUSSION}

In this soda delignification process, sodium hydroxide concentration and temperature was varied in order to obtain the optimum condition that would be corresponding with chemical contents (cellulose and lignin). The result showed in Figure 2 and Figure 3 for lignin composition and Figure 4 and Figure 5 for cellulose composition.

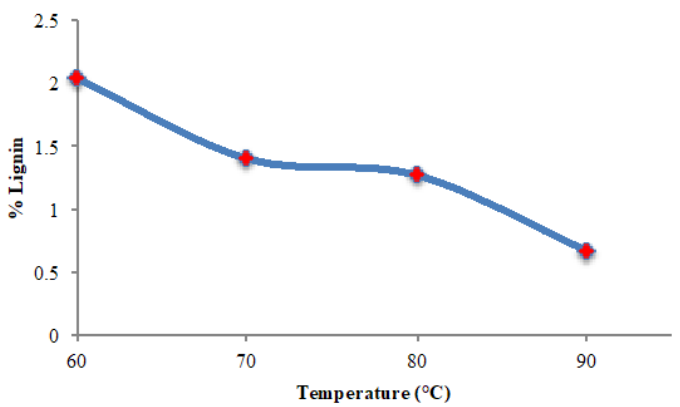

FIGURE 2. Effect of temperature of delignification process on lignin composition

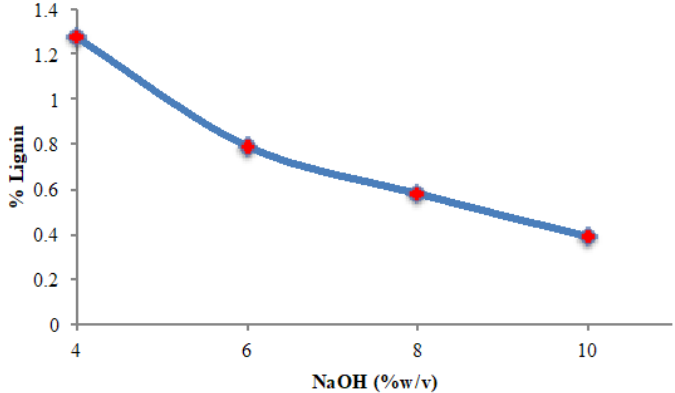

FIGURE 3. Effect of $\mathrm{NaOH}$ concentration of delignification process on lignin composition

In Figure 2, the effect of temperature on lignin composition was observed by varying the temperature in the range of $60-90^{\circ} \mathrm{C}$ in the concentration of $\mathrm{NaOH}$ at $4 \% \mathrm{w} / \mathrm{v}$. It showed that the lignin content in the tissue pulp decreased as the temperature of delignification increased. The higher the temperature in the delignification process (lignin removal process) would increase the delignification rate in the $\mathrm{NaOH}$ solution. Thus, the solubility of lignin in $\mathrm{NaOH}$ solution was increased. The increasing solubility of lignin in $\mathrm{NaOH}$ causes more lignin to be removed from corn husks, thus would be better quality of the pulp produced.

In Figure 3, the effect of $\mathrm{NaOH}$ concentration was considered by varying the concentration of $\mathrm{NaOH}$ in the range of $4-10(\% \mathrm{w} / \mathrm{v})$ at temperature of $80^{\circ} \mathrm{C}$. The time of delignification was 1.5 hours it showed that the lignin content in the pulp also decreased for the higher concentration of $\mathrm{NaOH}$. The increasing of the $\mathrm{NaOH}$ concentration means the increasing of $\left[\mathrm{OH}^{-}\right]$ions in the solution. These $\left[\mathrm{OH}^{-}\right]$ions will break the bonds between lignin and cellulose due to the hydroxide ion in the $\mathrm{NaOH}$ solution attack the carbonyl group on the lignin and break the ether bond in the lignin molecule. Furthermore, the lignin that has been separated from cellulose will bind with ions $\mathrm{Na}^{+}$to form sodium phenolate which is easily soluble [7-9]. In the temperature of $80^{\circ} \mathrm{C}$, and concentration of $\mathrm{NaOH}$ at $10 \% \mathrm{w} / \mathrm{v}$, the tissue paper had the lowest lignin content compared to other operating conditions.

The result of experimental data in Figure 2 and 3 were fitted with a second-order polynomial model by performing VIF (Variance Inflation Factor) to presented multi-correlation of each variables used. According to $\mathrm{p}<0.05$ indicated that the independent variables to dependent variables have significantly influence.

The concentration of $\mathrm{NaOH}$ as well as temperature has affected to lignin composition. Furthermore, the both of variables were not in interaction to lignin concentration. It has presented on VIF value in the range of $(1-5)$, that mean as multi-correlation has not been occurred. It also relates to each variable within have been same affected of lignin composition resulted. Whereas, the equation that fitted with the result has been showed in Equation1.

$$
\% \text { Lignin }=5,06-0,0430 \mathrm{~T}-0,127 \mathrm{C}
$$


The effect of temperature on cellulose composition was observed by varying the temperature of the delignification process in the range of $60-90^{\circ} \mathrm{C}$ in $\mathrm{NaOH}$ concentration at $4 \% \mathrm{w} / \mathrm{v}$. The effect of $\mathrm{NaOH}$ concentration was considered in the range of $4-10(\% \mathrm{w} / \mathrm{v})$ and the temperature of delignification at $80^{\circ} \mathrm{C}$. Each both of process was run in 1.5 hours. There were presented in Figure 4and Figure 5.

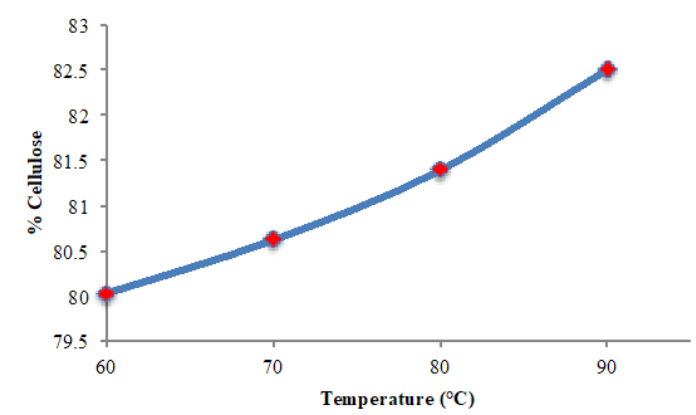

FIGURE 4. Effect of temperature of delignification process on cellulose composition

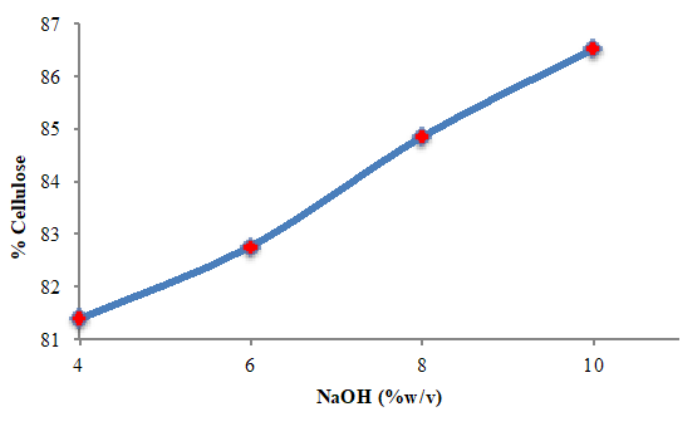

$\mathrm{S}$

FIGURE 5. Effect of $\mathrm{NaOH}$ concentration of delignification process on cellulose composition

In Figure 4, it showed that on $\mathrm{NaOH}$ concentration at 4\%, the higher temperature delignification will be followed by the increase of cellulose content in the tissue pulp. This is caused by the increasing of lignin solubility in the $\mathrm{NaOH}$ solution during temperature raising $[9,10]$. Then, the cellulose content in the tissue pulp would be depended on the lignin in the corn husks. If the lignin contained in the corn husks decreased in relating to the cellulose content in the corn husks will also increase. Thus, it explained the relationship between cellulose and lignin contain that removing the lignin can affect into the higher cellulose content of the tissue pulp. In Figure 5, at the delignification temperature of $80^{\circ} \mathrm{C}$, the higher of $\mathrm{NaOH}$ concentration will increase the cellulose content of the tissue pulp. Relating to the temperature effect, the cellulose content has been increasing due to decreasing of lignin contents in the tissue pulp [8].

According to the modelling of the equation for cellulose content, it was also analyzed statistically to determine the existence of multi-correlation each of predictor variables. Based on the data analysis, the predictor variables were no multi-correlation result among the predictor variables relating to the VIF value as below 5 . The VIF value analysis could be also shown that the two variables ( $T$ and $C$ ) have the same effect on the amount of cellulose content $(p<0.05)$. The equation model can be fitted by multiple regression methods, where the equation obtained was followed in Equation 2.

$$
\% \text { Cellulose }=71,8+0,0795 \mathrm{~T}+0,825 \mathrm{C}
$$

In order to obtain physical properties (tensile strength and water absorption), the tissue for all variation in temperature and $\mathrm{NaOH}$ concentration were characterized and compared with the commercial tissue. The results of the tensile strength for tissue produced from all variations in temperature and $\mathrm{NaOH}$ concentration showed almost the same results around $0.42 \mathrm{~N} / \mathrm{mm}^{2}$, therefore the selected tissue samples in the delignification process at a temperature of $90^{\circ} \mathrm{C}$ and $\mathrm{NaOH}$ concentration at $4 \% \mathrm{w} / \mathrm{v}$. In addition, the consideration is to choose the tissue paper produced in the delignification process at $90^{\circ} \mathrm{C}$ and a $\mathrm{NaOH}$ concentration of $4 \%$ because of the resulting tissue tends to be stronger and has a smoother surface, and the tissue has a brighter color than the delignification process conditions at $80^{\circ} \mathrm{C}$ and $\mathrm{NaOH}$ concentration of $10 \% \mathrm{w} / \mathrm{v}$. The selected sample was presented as tissue without additive (T1). The effect of adding additives such as chitosan on physical properties of tensile strength were compared to experimental tissue without additive (T1). In table 1 presented the comparison of tensile strength for experiment tissue to commercial tissues.

The tissue paper without additive (T1) had a tensile strength value that is close to toilet tissue (T5) as shown in Table 1 . The tensile strength value of tissue paper increases with the increase in the concentration of chitosan. The linear tensile strength value increases along with the increasing concentration of chitosan. Chitosan can interact with cellulose [11]. The interaction formed is in the form of a hydrogen bond between the (-OH) group on cellulose with the (-NH2) and (-OH) groups on chitosan. The more chitosan is added, the more hydrogen bonds are formed therefore the tensile strength increases [11,12].The tissue paper with the lowest concentration of chitosan has a tensile strength value that is close to commercial facial tissue (T6). 
TABLE 1. Tensile strength of experimental tissues and commercial tissues

\begin{tabular}{cc} 
Sample & $\begin{array}{c}\text { Tensile Strength } \\
\left(\mathrm{N} / \mathrm{mm}^{2}\right)\end{array}$ \\
\hline T1 1 & 0.42 \\
TCh2 & 0.83 \\
TCh4 & 0.83 \\
TCh6 & 0.83 \\
TCh8 & 1.25 \\
TCh10 & 2.08 \\
T5 & 0.45 \\
T6 & 0.83 \\
\hline
\end{tabular}

Note:

T1: tissue without additive

TCh2-TCh10: tissue with various concentration of chitosan $2 \%-10 \%$

T5: commercial toilet tissue

T6: commercial facial tissue

The tissue soaked in the chitosan solution caused some of the chitosan to occupy the pores and part of it only sticks to the surface of the tissue. There is a chemical similarity between cellulose and chitosan, therefore it could increase the strength of the fiber matrix through hydrogen bonds. [6]. The addition of chitosan to the resulting tissue could also increase the aesthetic value of the tissue, such as the brightness and smoothness could be increased [6], [12-14]

In general, physical properties important besides tensile strength is water absorption. The results of the water absorption test of experimental tissue and commercial toilet and facial tissue were 211,246 and $254 \mathrm{~g} / \mathrm{m}^{2}$ respectively. The water absorption is the ability of a paper to absorb water between its fibers [15]. Generally, paper can absorb water because of its hygroscopic nature. Water can bind with cellulose fibers to form solvation, causing the paper to soften and damage. Therefore, the amount of water that can be absorbed by the paper really depends on the fiber bonds in the paper. On the other hand, the increase in hydrogen bonding due to the increased concentration of chitosan and mangosteen peel added to the tissue paper prevents water from interacting with cellulose.

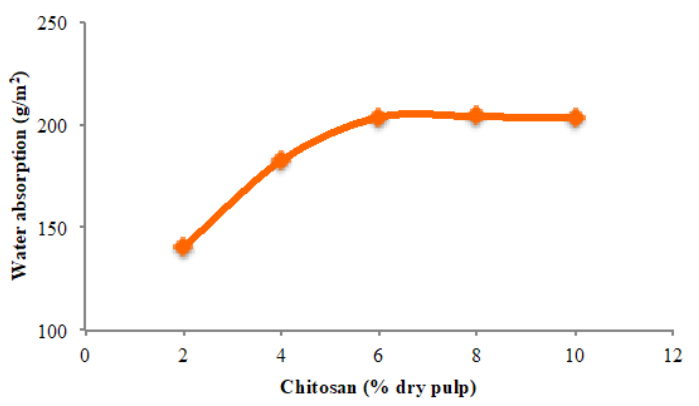

FIGURE 6. Effect of chitosan concentration against on water absorption at tissue paper

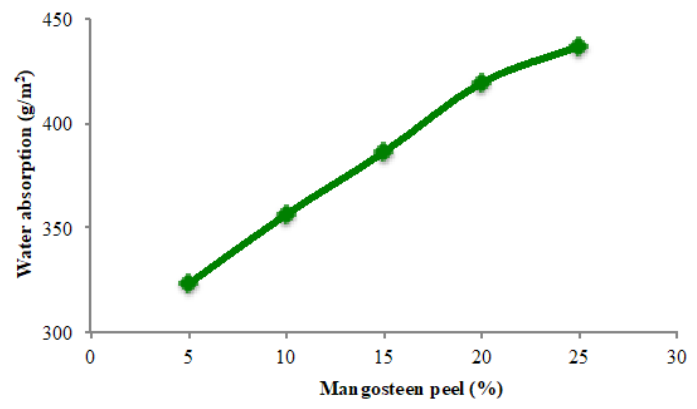

FIGURE 7. Effect mangosteen peel concentration on water absorption at tissue paper

The tissue with additive has influence the water absorption capacity, as shown in Figure 6 for chitosan and Figure 7 for mangosteen peel. The increasing of chitosan concentration tends to the water absorption increases, while in the chitosan concentration in the range of $6 \%-12 \%$ has a constant water absorption. The increasing of mangosteen peel concentration, hence the water absorption will increase. The concentration of chitosan at $12 \%$ and mangosteen peel at $25 \%$ have a water absorption of 204 and $437 \mathrm{~g} / \mathrm{m}^{2}$, respectively. Compared to tissue without additives, the addition of chitosan causes a slight decrease in water absorption, while the addition of mangosteen increased the water absorption up to $100 \%$. 


\section{CONCLUSIONS}

This optimum condition was obtained from corn husk delignification at $\mathrm{NaOH}$ concentration of $4 \%$, delignification temperature of $90^{\circ} \mathrm{C}$. The highest $\%$ cellulose and the lowest $\%$ lignin, tensile strength, water absorption were achieved at this optimum condition, such as $82.5 \%, 0.67 \%, 0.42 \mathrm{~N} / \mathrm{mm}^{2}$ and $211 \mathrm{gr} / \mathrm{m}^{2}$ respectively. The higher addition of mangosteen peel concentration increased the water absorption. For the variable mixture of corn husk with various composition of chitosan, the highest tensile strength of $2.08 \mathrm{~N} / \mathrm{mm}^{2}$ and water absorption of $204 \mathrm{gr} / \mathrm{cm}^{2}$ were achieved on $10 \%$ composition of chitosan. This investigation showed the potential of using the agricultural waste of corn husk for the tissue papermaking. The tissue from corn husk has achieved the adequate physical properties required, however it would more suitable if it is used as toilet tissue.

\section{ACKNOWLEDGMENTS}

The author wishes to thank Ms. Dyah Ayu Ambarsari for the technical assistance during the experiments conducted at Polymer and Membrane Laboratory of Surabaya University, East Java, Indonesia.

\section{REFERENCES}

1. Badan Pusat Statistik Jakarta Pusat. Produksi Jagung di Indonesia Menurut Provinsi (ton) (2015).

2. Rodríguez. A., Sánchez. R., Requejo. A., and Ferrer. A., Journal of Cleaner Production 18, 10, 1084-91 (2010).

3. Liu. Z., Wang. H., and Hui. L., InTechOpen 79017 (2014).

4. S. Janardhanan, J., Mahendra, A. S. S., Girija, L., Mahendra, and V. Priyadharsini, Journal of Clinical and Diagnostic Research 11, 1, 19-22 (2017).

5. Gondokesumo, M.E., Pardjianto, B., Sumitro, S.B., Widowati, W., Handono, K., Pharmacogn Journal11, 2, 369373 (2019).

6. Zakaria, S., et all, Sains Malaysiana 44, 6, 905-911 (2015).

7. Sundquist, J., Chemical Pulping at Paper making Science and Technology, Helsinky Finland (1999).

8. Harun S., and Geok. S. K., "E, Indian Journal of Science and Technology9, 21 (2016).

9. Saleh, A. Hassan and Jafferi, N., ARPN Journal Engineering and Applied Sciences, 11,12 (2016).

10. M. Aremu, M. Rafiu, A., International Research Journal of Engineering and Technology, 2, 4, 1180-1188 (2015).

11. Suseno, N., Sapei, L., Purwanto, E., and Adiarto, T., AIP Conf, 080002 (2017).

12. Suseno, N., Padmawijaya, K. S., S. Andree, K. Nathanael, Majalah Polimer Indonesia, 18, 1, 33-39 (2015).

13. H. Li, Y. Du, and Y. Xu, Journal of Applied Polymer Science, 91, 2642-2648 (2004).

14. H. Agusnar and I. Nainggolan, Advances in Environmental Biology, 7, 12, 3857-3860 (2013).

15. Gigac, J., Fišerová, M., Stankovsk, M., and Maholányiova, M., O Papel 80, 8, 91 - 97 (2019). 